\title{
Determination of fighting styles of qualified veteran boxers based on cluster analysis of biomechanical and psychophysiological indicators
}

\author{
Kozin V.Yu. ${ }^{1 \mathrm{ABCD}}$, Falova O.Ye. ${ }^{2 \mathrm{CDE}}$, Cretu M. ${ }^{3 \mathrm{BCD}}$, Cieślicka M. ${ }^{4 \mathrm{BCD}}$ \\ ${ }^{1}$ Kinesiology laboratory, H.S. Skovoroda Kharkiv National Pedagogical University, Kharkiv, \\ Ukraine \\ ${ }^{2}$ Department of Practical Psychology, Ukrainian Engineering Pedagogics Academy, Kharkiv, \\ Ukraine \\ ${ }^{3}$ Faculty of Science, Physical Education and Informatics, University of Pitesti, Pitesti, \\ Arges, Romania \\ ${ }^{4}$ Gdansk University of Physical Education and Sport in Gdansk, Poland
}

Authors' Contribution: A - Study design; B - Data collection; C - Statistical analysis; D Manuscript Preparation; E- Funds Collection

DOI: https://doi.org/10.34142/HSR.2021.07.04.02

Corresponding author: Kozin V.Yu., kozin.v.yu@gmail.com, http://orcid.org/0000-0003-2561-8803, Kinesiology laboratory, H.S. Skovoroda Kharkiv National Pedagogical University, Altshevskih str. 29, Kharkiv, 61002, Ukraine

\section{How to Cite}

Kozin VYu, Falova OYe, Cretu M, Cieślicka M. Determination of Fighting Styles of Qualified Veteran Boxers based on Cluster Analysis of Biomechanical and Psychophysiological Indicators. Health, Sport, Rehabilitation. 2021;7(4):19-34. https://doi.org/10.34142/HSR.2021.07.04.02

\begin{abstract}
Purpose: to reveal the styles of fighting veteran boxers on the basis of a multivariate analysis of psychophysiological and biomechanical indicators.

Material and methods. The study involved 42 qualified veteran boxers (age 45-50 years). As research methods, we used a biomechanical analysis of the indicators of the speed of movement of various points and the values of the angles in the joints when performing a direct blow by boxers. The psychophysiological method was used to determine the time of a simple and complex reaction under standard conditions and in various testing modes. We used the method of cluster analysis to distribute athletes into groups using the SPSS - 17.0 program. Within the groups, the athletes are as similar as possible to each other in terms of the analyzed indicators, and between the groups they differ as much as possible. The analysis of the groups of athletes obtained with the help of cluster analysis made it possible to identify athletes with the following styles of fighting: tempo, game, power. Results. Cluster analysis of psychophysiological and biomehanical testing showed the presence of 3 groups of athletes. The clusters were named as follows: Cluster 1 - "Speed and coordination endurance", corresponds to the boxers of the pace of the fight; Cluster 2 - "Speed", corresponds to the boxers of the game style of fighting; Cluster 3 - "Strength and speed", corresponds to the boxers of the pace of the fight. Biomechanical features of boxers of different styles of fighting are reflected in the trajectories of the points of the fist, elbow, knee.

Conclusions. The results of this study should be used when planning the individual training of athletes in boxing and to determine the optimal style of competitive competition for qualified veteran boxers. The proposed methods of psychophysiological and biomechanical testing to determine the individual characteristics of boxers are an effective, fairly accessible and convenient tool for revealing the predisposition of boxers to a certain style of fighting.
\end{abstract}

Key words: technique, boxing, cluster, neurodynamics, speed, joint angle, physiology, psychology 


\section{Аннотация}

Козин В.Ю., Фалева О.Є., Крету М., Ягелло М. Определение стилей ведения поединка квалифицированных боксеров-ветеранов на основе кластерного анализа биомеханических и психофизиологических показателей

Цель: выявить стили ведения поединка боксеров-ветеранов на основе многомерного анализа психофизиологических и биомеханических показателей.

Материал и методы. В исследовании приняли участие 42 квалифицированных боксера-ветерана (возраст 45-50 лет). В качестве методов исследования испольльзовался биомеханический анализ показателей скорости движения различных точек и значеия углов в суставах при выполении прямого удара боксерами. Использовался психофизиологический метод определения времени простой и сложной реакции в стандартных условиях и в различных режимах тестирования. Мы использовали метод кластерного анализа для распределения атлетов на группы с помощью программы SPSS - 17.0. Внутри групп атлеты максимально схожи между собой по анализируемым показателям, а между группами - максимально различаются между собой. Анализ полученных с помощью кластерного анализа групп атлетов позволил выявить атлетов со следующими стилями ведения поединка: темповой, игровой, силовой.

Результаты. Кластерный анализ показателей психофизиологического и биомеханического тестирования показал наличие 3-х групп атлетов. Кластеры были названы следующим образом: кластер 1 - «Скоростная и координационная выносливость», отвечает боксерам темпового стиля ведения поединка; кластер 2 «Скорость», отвечает боксерам игрового стиля ведения поединка; кластер 3 - «Сила и скорость», отвечает боксерам темпового стиля ведения поединка. Биомеханические особенности боксеров разных стилей ведения поединка отражаются в траекториях движения точек кулака, локтя, колена.

Выводы. Результаты данного исследования целесообразно использовать при планировании индивидуальной подготовки атлетов в боксе и для определения оптимального стиля ведения соревновательного поединка для квалифицированных боксеров-ветеранов. Предложенные методы психофизиологического и биомеханического тестирования для определения индивидуальных особенностей боксеров являются эффективным, достаточно доступным и удобным в применении средством выявления предрасположенности боксеров к определенному стилю ведения поединка.

Ключевые слова: техника, бокс, кластер, нейродинамика, скорость, угол в суставе, физиология, психология 


\section{Introduction}

At the present stage of boxing development, the style of fighting is a characteristic feature of every professional boxer $[1,2,3]$. Yes, there are boxers who are very forceful in the fight. They are distinguished by the great force of the blow, the desire for power victory of the enemy. Such boxers include Mike Tyson, Vitali Klitschko, George Foreman, David Tua and other attacking "security officers" $[4,5,6]$. Some boxers fight, constantly varying their actions, using a lot of feints, strikes in the most unexpected moments. These are boxers of game style - Roy Jones, Mohammed Ali, Floyd Mayweather [2, 3, 4]. There are boxers who "exhaust" the opponent at a high pace for many rounds, and win when the opponent is no longer able to withstand the imposed pace. These are boxers of tempo style - Manny Pacquiao, Joe Fraser and others $[7,8]$. The most successful option is the ability to combine different styles, and in different battles to show different ways of fighting. However, the most characteristic features of the movements of athletes remain unchanged, which gives reason to talk about the predominant individual style of fighting.

The doctrine of activity styles and, in particular, of fighting styles, has its roots in antiquity $[1,2,9]$. To date, the nature of the origin of different styles is not fully understood. There are hypotheses that suggest that the styles occurred as a result of separate training of certain groups of people $[1,9]$. There are also historical facts that indicate the origin of the styles of dueling as an imitation of the manners of movement and survival strategies of different animals [9]. Thus copying was carried out both external movements, and internal states. Martial arts from the "crane style" have come down to our time, as well as different styles of fighting within one martial art.

There are a number of styles of wushu, united by the common name of xiang xinquan - "style of image and form" or "style of imitation of form." They are based on imitating the movements and habits of animals. In Xinxingquan, the state of naturalness, spontaneous looseness (jizhan) is achieved through complete self-identification with the selected object, not only external, but most importantly, internal. Man, mastering the "form and manner" of the tiger, snake, dragon, reached the natural looseness and natural power of the animal in its "original state" [10, 11].

Imitation of animal movements has been known in China for a long time [1]. In early totem dances, the ancestors of the Chinese imitated the manner of fighting the animal. The doctrine of activity styles and, in particular, of fighting styles, has its roots in antiquity. There are historical facts that indicate the origin of the styles of dueling as an imitation of the manners of movement and survival strategies of different animals. Thus copying was carried out both external movements, and internal states. It is logical to assume that the physiological basis of style formation is relatively constant genetically determined functions, such as neurodynamic processes and psychophysiological capabilities $[12,13]$, and registration of these indicators in the training process will help determine the propensity of a boxer to a certain style of fighting.

There are many different methods for measuring psychophysiological functions $[14,15]$. At present, methods of studying psychophysiological functions are becoming more widespread, which make it possible to determine not only the reaction rate, the sense of time, but also the typological properties of the nervous system: strength, mobility, resistance to stimuli in time [15, 16-18].

Currently, the study of psychophysiological functions [19-22] in connection with the individual characteristics of the technique of movements, according to biomechanical indicators [23-25], is of great importance. This makes it possible to quantitatively determine how and how the peculiarities of brain activity affect the formation of an individual style of human activity. For this purpose, qualified veteran boxers are one of the most suitable contingents for such studies for several reasons [26]: 1 - as a person's age increases, there is an improvement in technical skill while continuing to engage in a certain type of activity, including sports; 2 - as the age increases, the manifestation of individual psychological and psychophysiological traits occurs; 3 - the study of the peculiarities of technical skill of qualified middle-aged and elderly athletes in conjunction with the individual characteristics of psychophysiological functions is important as a tool for cognition of motor and psychophysiological manifestations of various styles of activity. However, there is much less scientific research on veteran athletes today than on younger active athletes.

In our previous studies [26], an attempt was made to determine the individual styles of fighting qualified veteran boxers on the basis of individual factor values of the analysis of psychophysiological and biomechanical indicators. With the help of factor analysis, carried out by the method of principal components, in the structure of complex readiness of qualified veteran boxers, 2 main factors were identified: "Speed" and "Speed and coordination endurance". Further, the individual factor structure of the athletes' readiness was found on the basis of 
determining the percentage values of the severity of each factor in each boxer. All athletes have different severity of various factors, which indicates the presence of significant individual differences. This should be manifested in different styles of fighting and the need to use individual training programs for qualified veteran boxers [26].

Our previous studies have also shown that for an accurate distribution of veteran boxers according to fighting styles, it is necessary to use modern methods of mathematical statistics, in particular, cluster analysis [26]. Thus, this work is a continuation of our previous research to determine the fighting styles of qualified veteran boxers. In the presented work, it was assumed that a multivariate analysis of psychophysiological and ergonomic indicators would allow the athletes to be divided into groups that would correspond to different styles of fighting qualified veteran boxers.

Purpose: to reveal the styles of fighting veteran boxers on the basis of a multivariate analysis of psychophysiological and biomechanical indicators.

\section{Material and methods}

\section{Participants}

The study involved 42 qualified veteran boxers (age 45-50 years, body length $-178.67 \pm$ $8.26 \mathrm{~cm}$, body weight $-70.96 \pm 9.38 \mathrm{~kg}$ ). The total experience of boxing for the participants was $20-25$ years. Athletes were selected as follows: a prerequisite for participation in the study was the presence of a sports qualification in the past not lower than a candidate for master of sports (the winners of competitions not lower than the level of the city and region) and the regularity of training for the last 10 years $3-4$ times a week. The study was carried out on the basis of sports clubs "KhTZ", "Vostok", "Metalist" in Kharkov, Ukraine.

All participants were aware of the objectives of the study and agreed to participate. All participants gave written consent to participate in the study. The research was conducted in compliance with WMA Declaration of Helsinki - Ethical Principles for Medical Research Involving Human Subjects, 2013.

\section{Procedure}

The study was conducted from April 18 to May 25, 2021. At the beginning, athletes were filmed while performing a direct blow in boxing. Each athlete performed a series of strikes alternately with the right and left hands in the training session against the background of a visible object for subsequent calibration with known dimensions. Video filming was carried out at training sessions from 18-00 after a short warm-up in the boxing gym of the KhTZ sports club. During one training session, $10-12$ people were filmed. The next day after the video filming, the athletes underwent psychophysiological testing also from 18-00. When conducting psychophysiological testing, athletes were initially asked to pass the proposed tests in a training mode. Psychophysiological testing was carried out in the classroom for theoretical studies of the sports club "KhTZ".

\section{Biomechanical Analysis of Direct Punch Technique in Boxing}

We have chosen the direct punch as the main element for the analysis of the athletic technique of qualified veteran boxers. The choice of the direct hit was due to the fact that it is the main technical element in boxing [26, 27, 28]. This stroke is the most standardized of all boxing elements and provides the least variability in execution. This element is perfectly mastered by all qualified boxers, in particular - veteran boxers. Also, the individual style of movements is most traced precisely in those movements performed most automatically, that is, with minimal control from the side of consciousness. This blow is the most convenient for biomechanical analysis using video filming, since it is performed practically in the same plane.

Biomechanical analysis of the direct kick technique in qualified veteran boxers was carried out using the Kinovea software, version 0.8.15. (Fig. 1). The Kinovea program allows performing video analysis of movements [29, 30]. It is intended for athletes, coaches, healthcare professionals, and sports research. Also, the software can be useful for specialists in the field of ergonomics or animation. The main function of Kinovea is to view and analyze sports videos. The main tools used by users are "Line", "Chronometer", "Tracking", "Angles". The Line and Chronometer functions allow you to measure distance and time, while the Semi-automatic tracking tool can track both the path and time. When working with Kinovea, you can use video from external sources: video cameras, smartphones, and so on.

To analyze the biomechanical parameters of the direct strike technique of qualified veteran boxers, 6 frames were selected at a speed of 26 frames per second. Thus, the time of one frame was 0.03-0.04 s (Fig. $1-3$ ). The duration of the direct impact was $0.13-0.16 \mathrm{~s}$, depending on how many frames were analyzed ( 5 or 6 , respectively). Distance 
calibration was carried out along the length of a special device, against the background of which video filming was carried out $(138 \mathrm{~cm})$. The movement time was determined by the stopwatch indicators in the program. The speed of movement of the fist, shoulder joint, elbow joint, knee joint was determined $\left(\mathrm{V}, \mathrm{m} \cdot \mathrm{s}^{-1}\right)$ (Fig. 2). Determination of the angles between the shoulder and the torso (the angle at the shoulder joint), between the shoulder and the forearm (the angle at the elbow joint), between the thigh and the lower leg (angle at the knee joint) (degrees) also worked (Fig. 1).

A total of 10 videos of direct kick were analyzed for each athlete. Averaged data for each athlete was analyzed from 10 videos. The total number of video recordings was 420 . The point of the greatest extension of the striking arm in the shoulder joint was chosen as the end of the impact. In each video, 6 frames were selected for analysis (duration of a direct impact). If the impact ended on the fifth frame, then the sixth frame was excluded from the analysis. Earlier in the fifth frame, more than one athlete did not end the direct hit. Thus, the total duration of a direct blow in boxing among qualified veteran boxers was $0.13-0.16 \mathrm{~s}$. The point of the minimum angle between the shoulder and the torso (shoulder joint), from which the movement of the striking arm begins $[26,29,30]$, was chosen as the beginning of the impact.

To analyze the angles in the joints, the "Angles" tool was selected on the toolbar of the Kinovea 0.8.15 program. The point of the apex of the angle was selected, then the angle for analysis was determined. The angle chosen for analysis was determined in each frame (Fig. 1).

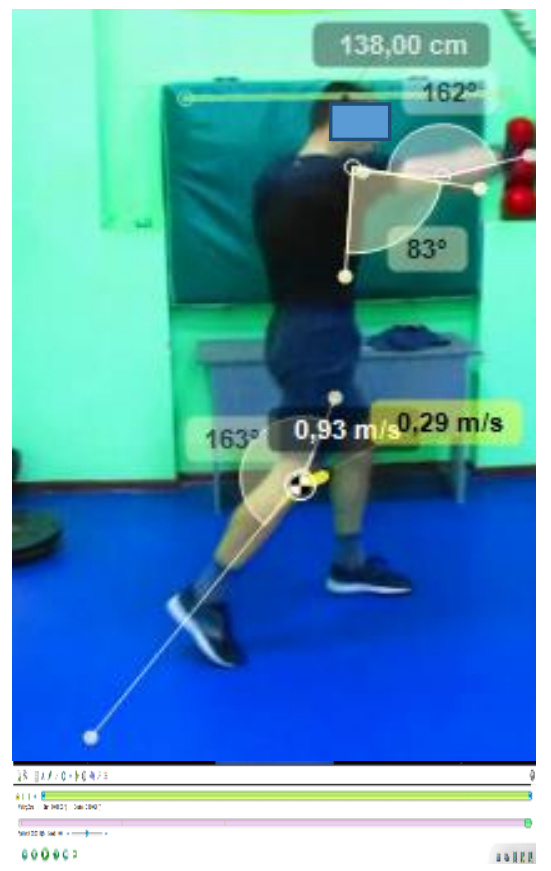

Fig. 1. Determination of the speed of movement of various points of the body and angles in the joints when performing a direct blow in boxing using the Kinovea 08.15 program

We carried out the following trajectory tracking for the subsequent analysis of the distance and speed of movement of each point (Fig. 1): 1 we chose a point for analysis; 2 - select the "Track Path" option; choose the "End Path Edition" function; 3 - the analyzed point was corrected for each frame; 4 - Select the "Configuration" function and set the "Distance" function. The display showed the distance from the beginning of the movement to the selected segment of the path. To measure the speed of a point, we selected the "Configuration" function, and then we selected the "Speed" function. We chose meters per second as the unit of measurement. The measurement results were exported to the EXCEL program.

\section{Psychophysiological methods}

The following parameters characteristic of the psychophysiological state, typological features of the nervous system, indicators of the nervous system efficiency, and attention indicators $[12,14,15]$ have been set using the computer program "Psychodiagnostics" (Kharkiv, Ukraine, KhNPU):

- A set of indices for the time of a simple visual-motor reaction (mean of 30 attempts (ms), 
standard deviation (ms), number of errors); duration of exposure (signal) - $900 \mathrm{~ms}$.

- A set of indicators of a complex visualmotor reaction of selecting 2 element from 3 (mean value of 30 attempts (ms), standard deviation (ms), number of errors); duration of exposure (signal) $900 \mathrm{~ms}$.

- A set of indicators of a complex visualmotor reaction of selecting 2 elements out of 3 in the feedback mode, i.e. as the response time changes, the signal delivery time changes. The 'short version' is carried out in the feedback mode, when the duration of exposure changes automatically depending on the response of the subject: after a correct answer, the duration of the next signal is reduced by $20 \mathrm{~ms}$, and after a wrong one, it increases by the same amount. The range of the signal exposure change during the test subject's operation is $20-900 \mathrm{~ms}$, with a pause between exposures of $200 \mathrm{~ms}$. The correct answer is to press the left (right) mouse button while displaying a certain exposure (image), or during a pause after the current exposure. In this test, the time to reach the minimum exposure of the signal and the time of the minimum exposure of the signal reflect the functional mobility (speed) of the nervous processes; the number of errors reflects the strength of the nervous processes (the lower these parameters, the higher the speed endurance of the nervous system). The duration of the initial exposure is $900 \mathrm{~ms}$; the amount of change in the duration of the signals with correct or erroneous responses is $20 \mathrm{~ms}$; pause between the presentation of signals - $200 \mathrm{~ms}$; the number of signals is 50 . The indicators are fixed: the average value of the latent period (ms); root mean square deviation (ms); number of mistakes; time of test execution (s); minimum exposure time (ms); time of exposure to the minimum exposure (s).

\section{Statistical analysis}

We used the method of cluster analysis to distribute athletes into groups using the SPSS - 17.0 program. Within the groups, the athletes are maximally similar to each other in terms of the analyzed indicators, and between the groups they differ as much as possible [31-33]. The analysis of the groups of athletes obtained with the help of cluster analysis made it possible to identify athletes with the following styles of fighting: tempo, playing, strength styles.

When conducting cluster analysis, we used the following options of the SPSS program: Analyze - Classify - Hierarchical cluster analysis. We first printed the Agglomeration Schedule table without setting the estimated number of clusters. Based on the values of the coefficients in the table
"Agglomeration Schedule" during the formation of clusters, we have determined the optimal number of clusters for our study. To do this, we subtracted the step number from the total number of cases (42), after which the increase in the coefficients occurs nonlinearly (39). As a result, we got the optimal number of clusters equal to 3 . Next, we performed the cluster analysis again, setting the Cluster Membership - Single solution option. We set the number of clusters to 3 . Thus, we got the cluster membership of each athlete. Further, we combined the results of determining individual factor values in absolute and relative terms with the results of the distribution of athletes into clusters (groups). Based on the prevalence of the severity of various factors in each group of athletes, we gave a name to each cluster.

\section{Results}

The test for normality of distribution of test indicators showed that all test indicators correspond to the normal distribution (Asymptomatic significance according to the Chi-square test> 0.05; Significance according to the Monte Carlo test> 0.05) [26]. The distribution of indicators of the analyzed sample does not significantly differ from the Gaussian normal distribution.

To determine the optimal options for combining qualified veteran boxers into groups based on the principle of different styles of fighting, a cluster analysis of testing indicators was carried out. The results of the cluster analysis were compared with the individual factor values, and the profiles of the athletes were drawn up. On the basis of the data obtained, the individual characteristics of qualified veteran boxers were determined by the prevalence of factors in the individual structure of preparedness and the corresponding styles of fighting.

In hierarchical cluster analysis, each individual case first forms its own separate cluster. At each step, two separate clusters that are closest to each other in their structure are combined into one cluster. First, the athletes who are closest in terms of the analyzed indicators are united, then athletes who are similar in the analyzed indicators join the formed pairs. Thus, groups of athletes appear, which can be considered as the groups most similar in their structure to the preparedness of the subjects.

Clusters were determined according to the degree of "similarity" of athletes according to the indicators of complex testing (Tables 1, 2, Fig. 2). In order to find out how many clusters are optimal, one should subtract the step number from the number of analyzed athletes, from which the cluster coefficients 
begin to grow nonlinearly. In our case, this is step 39 (Table 1). Based on this, $42-39=3$. That is, the optimal number of clusters is 3 clusters.

The first cluster included athletes No. 2; 5, 8; eleven; fourteen; 17 ; twenty; $23 ; 26 ; 29 ; 41(n=11)$ (Tables 1, 2, Fig. 2). The second cluster includes athletes No. $1 ; 4,7,10,13 ; 16 ; 19 ; 22 ; 25 ; 28 ; 31 ; 32$; $34 ; 37 ; 38 ; 40(\mathrm{n}=16)$ (Tables 1,2 , Fig. 2). The third cluster included athletes No. 3, No. 6; nine; 12; 15; eighteen; $21 ; 24 ; 27$; thirty; 33; 35; 36; 39; 42 ( $\mathrm{n}=$ 15) (Tables 1, 2, Fig. 2). The stages of the combination of athletes into clusters are presented in
Table 1. It can be seen from the table that at the first stage athletes No. 39 and No. 42 are united, in the next step athletes No. 38 and No. 41 are united. In the third step, athletes No 37 and No 40 are united. At the fourth step, athlete No 3 joins athletes 39 and 42 . At the fifth step, athlete No 2 joins athletes No 38 and 41. At the sixth step, athlete No 1 joins athletes No 37 and 40. Further, each group of athletes is alternately replenished with the next veteran boxer. In total, 41 steps were taken to unite veteran boxers into clusters, 1 less than the number of athletes (42).

Agglomeration Schedule in cluster analysis of biomechanical and psychophysiological indicators of qualified veteran boxers

\begin{tabular}{|c|c|c|c|c|c|c|}
\hline \multirow{2}{*}{ Stage } & \multicolumn{3}{|c|}{ Cluster Combined } & \multicolumn{2}{|c|}{ Stage Cluster Last Appears } & \multirow{2}{*}{ Next Stag } \\
\hline & Cluster 1 & Cluster 2 & Coefficients & Cluster 1 & Cluster 2 & \\
\hline 1 & 39 & 42 & 0.153 & 1 & 1 & 4 \\
\hline 2 & 38 & 41 & 1.342 & 1 & 1 & 5 \\
\hline 3 & 37 & 40 & 2.412 & 1 & 1 & 6 \\
\hline 4 & 3 & 39 & 3.141 & 1 & 1 & 10 \\
\hline 5 & 2 & 38 & 4.2705 & 1 & 2 & 11 \\
\hline 6 & 1 & 37 & 5.2739 & 1 & 3 & 12 \\
\hline 7 & 33 & 36 & 6.2773 & 1 & 1 & 10 \\
\hline 8 & 32 & 35 & 7.2807 & 1 & 1 & 11 \\
\hline 9 & 31 & 34 & 8.2841 & 1 & 1 & 12 \\
\hline 10 & 3 & 33 & 9.2875 & 4 & 7 & 16 \\
\hline 11 & 2 & 32 & 10.2909 & 5 & 8 & 17 \\
\hline 12 & 1 & 31 & 11.2943 & 6 & 9 & 18 \\
\hline 13 & 27 & 30 & 12.2977 & 1 & 1 & 16 \\
\hline 14 & 26 & 29 & 13.3011 & 1 & 1 & 17 \\
\hline 15 & 25 & 28 & 14.3045 & 1 & 1 & 18 \\
\hline 16 & 3 & 27 & 15.3079 & 10 & 13 & 22 \\
\hline 17 & 2 & 26 & 16.3113 & 11 & 14 & 23 \\
\hline 18 & 1 & 25 & 17.3147 & 12 & 15 & 24 \\
\hline 19 & 21 & 24 & 18.3181 & 1 & 1 & 22 \\
\hline 20 & 20 & 23 & 19.3215 & 1 & 1 & 23 \\
\hline 21 & 19 & 22 & 20.3249 & 1 & 1 & 24 \\
\hline 22 & 3 & 21 & 21.3283 & 16 & 19 & 28 \\
\hline 23 & 2 & 20 & 22.3317 & 17 & 20 & 29 \\
\hline 24 & 1 & 19 & 23.3351 & 18 & 21 & 30 \\
\hline 25 & 15 & 18 & 24.3385 & 1 & 1 & 28 \\
\hline 26 & 14 & 17 & 25.3419 & 1 & 1 & 29 \\
\hline 27 & 13 & 16 & 26.3453 & 1 & 1 & 30 \\
\hline 28 & 3 & 15 & 27.3487 & 22 & 25 & 34 \\
\hline 29 & 2 & 14 & 28.3521 & 23 & 26 & 35 \\
\hline 30 & 1 & 13 & 29.3555 & 24 & 27 & 36 \\
\hline 31 & 9 & 12 & 30.3589 & 1 & 1 & 34 \\
\hline 32 & 8 & 11 & 31.3623 & 1 & 1 & 35 \\
\hline 33 & 7 & 10 & 32.3657 & 1 & 1 & 36 \\
\hline 34 & 3 & 9 & 33.3691 & 28 & 31 & 37 \\
\hline 35 & 2 & 8 & 34.3725 & 29 & 32 & 38 \\
\hline 36 & 1 & 7 & 35.3759 & 30 & 33 & 39 \\
\hline 37 & 3 & 6 & 36.3793 & 34 & 1 & 41 \\
\hline 38 & 2 & 5 & 37.3827 & 35 & 1 & 40 \\
\hline
\end{tabular}




\begin{tabular}{|c|c|c|c|c|c|c|}
\hline \hline 39 & 1 & 4 & 38.3861 & 36 & 1 & 40 \\
\hline 40 & 1 & 2 & 267.014 & 39 & 38 & 41 \\
\hline 41 & 1 & 3 & 612.816 & 40 & 37 & 0 \\
\hline
\end{tabular}

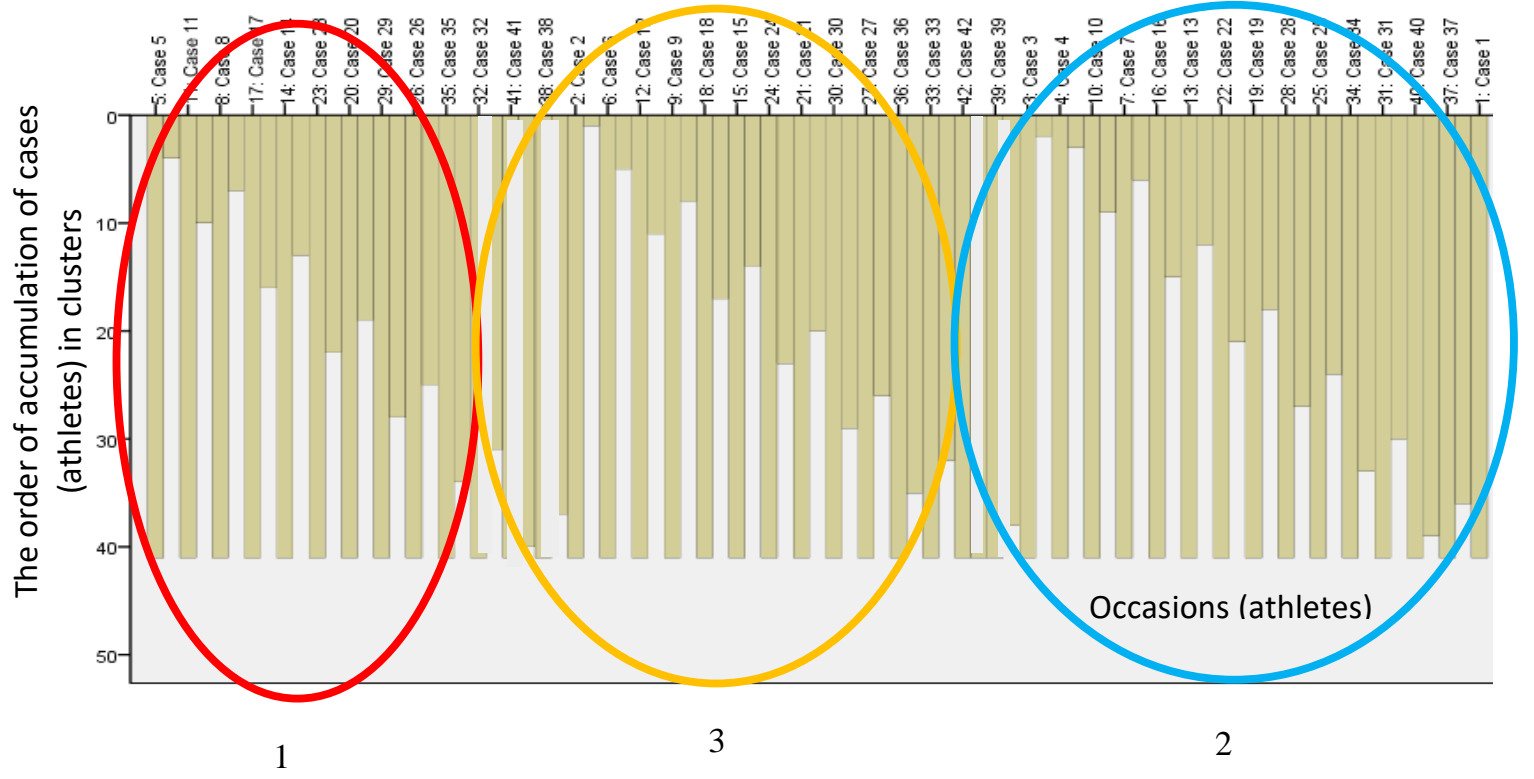

Fig. 2. Distribution of qualified veteran boxers into clusters:

1 - cluster $1 ; 2$ - cluster $2 ; 3$ - cluster 3

Thus, we received 3 clusters (groups) of veteran boxers, differing in their psychophysiological and biomechanical indicators. The athletes of these groups have different severity of factors in the individual structure of preparedness (Table 2). Individual severity of factors in the structure of preparedness of qualified veteran boxers was determined by us in our previous studies [26].

In the presented study, we found that in the athletes of the first cluster, the severity of the factor "Speed and coordination endurance" (more than $80 \%$ ) and a small level of severity of the factor "Speed" (less than 30\%) prevail. In athletes of the second cluster, the severity of the "Speed" factor (more than $80 \%$ ) and the average severity of the "Speed and coordination endurance" factor (about $50 \%$ ) prevail. Athletes of the third cluster have an average severity of the "Speed" factor (about 50\%) and a small severity of the "Speed and coordination endurance" factor (less than 30\%) (Table 2).

If we consider examples of factor models [26], built on the basis of individual values of the factor structure of veteran boxers (Table 2), it can be noted that the athletes of the first cluster have the most pronounced factor "Speed and coordination endurance". This means that these athletes are distinguished by their ability to maintain high speed and accuracy (coordination) of actions for a long time. That is why we named this cluster "Speed and coordination endurance". This cluster (group) of athletes in terms of their performance can be attributed to the style of fighting, requiring a high level of endurance with the support of a relatively high speed of movements. This is a style of fighting - tempo. In the athletes of the second cluster, the development of the first factor "Speed" and the average severity of the factor "Speed and coordination endurance" prevail. That is, these athletes are capable of high - speed actions at the beginning of movements and in average expressiveness of speed and coordination endurance. These qualities are most typical for boxers with a style of fighting - playing. Athletes of the third cluster have an average severity of the "Speed" factor and a small severity of the "Speed and coordination endurance" factor. We did not measure strength in this study because biomechanical analysis does not represent strength capability. We can draw conclusions indirectly about the manifestation of strength abilities. These athletes are characterized by the manifestation of speed with low endurance. Therefore, we named this cluster "Strength and Speed". This most characterizes the style of fighting - power. 
Table 2

Cluster Membership and individual severity of the factors of qualified veteran boxers based on the analysis of biomechanical and psychophysiological indicators

\begin{tabular}{|c|c|c|c|c|c|}
\hline \multirow[t]{2}{*}{ Occasions } & \multirow[t]{2}{*}{ Clusters } & \multicolumn{2}{|c|}{$\begin{array}{l}\text { Absolute individual values of } \\
\text { factors }\end{array}$} & \multicolumn{2}{|c|}{$\begin{array}{c}\text { Individual values of factors, expressed as a } \\
\text { percentage of the maximum values in a sample } \\
\text { of athletes }\end{array}$} \\
\hline & & Factor 1 & Factor 2 & Factor 1 & Factor 2 \\
\hline 1 & 2 & 35.50 & 21.50 & 84.52 & 51.19 \\
\hline 2 & 1 & 7.50 & 35.50 & 17.86 & 84.52 \\
\hline 3 & 3 & 21.50 & 7.50 & 51.19 & 17.86 \\
\hline 4 & 2 & 34.68 & 20.72 & 83.19 & 50.26 \\
\hline 5 & 1 & 7.68 & 35.79 & 19.65 & 85.64 \\
\hline 6 & 3 & 19.86 & 6.48 & 52.28 & 18.75 \\
\hline 7 & 2 & 35.50 & 21.50 & 84.52 & 51.19 \\
\hline 8 & 1 & $7, .50$ & 35.50 & 17.86 & 84.52 \\
\hline 9 & 3 & 21.50 & 7.50 & 51.19 & 17.86 \\
\hline 10 & 2 & 34.68 & 20.72 & 83.19 & 50.26 \\
\hline 11 & 1 & 7.68 & 35.79 & 19.65 & 85.64 \\
\hline 12 & 3 & 19.86 & 6.48 & 52.28 & 18.75 \\
\hline 13 & 2 & 35.50 & $2 ., 50$ & 84.52 & 51.19 \\
\hline 14 & 1 & 7.21 & 38.64 & 15.59 & 85.58 \\
\hline 15 & 3 & 21.50 & 7.50 & 51.19 & 17.86 \\
\hline 16 & 2 & 34.68 & 20.72 & 83.19 & 50.26 \\
\hline 17 & 1 & 7.21 & 38.64 & 15.59 & 85.58 \\
\hline 18 & 3 & 19.86 & 6.48 & 52.28 & 18.75 \\
\hline 19 & 2 & 34.68 & 20.72 & 83.19 & 50.26 \\
\hline 20 & 1 & 7.50 & 35.50 & 17.86 & 84.52 \\
\hline 21 & 3 & 21.50 & 7.50 & 51.19 & 17.86 \\
\hline 22 & 2 & 35.50 & 21.50 & 84.52 & 51.19 \\
\hline 23 & 1 & 7.21 & 38.64 & 15.59 & 85.58 \\
\hline 24 & 3 & 21.67 & 8.50 & 56.19 & 18.86 \\
\hline 25 & 2 & 34.68 & 20.72 & 83.19 & 50.26 \\
\hline 26 & 1 & 7.50 & 35.50 & 17.86 & 84.52 \\
\hline 27 & 3 & 21.50 & 7.50 & 51.19 & 17.86 \\
\hline 28 & 2 & 34.68 & 20.72 & 83.19 & 50.26 \\
\hline 29 & 1 & 7.68 & 35.79 & 19.65 & 85.64 \\
\hline 30 & 3 & 19.86 & 6.48 & 52.28 & 18.75 \\
\hline 31 & 2 & 35.50 & 21.50 & 84.52 & 51.19 \\
\hline 32 & 2 & 21.67 & 8.50 & 56.19 & 18.86 \\
\hline 33 & 3 & 21.67 & 8.50 & 56.19 & 18.86 \\
\hline 34 & 2 & 35.50 & 21.50 & 84.52 & 51.19 \\
\hline 35 & 3 & 7.21 & 38.64 & 15.59 & 85.58 \\
\hline 36 & 3 & 21.50 & 7.50 & 51.19 & 17.86 \\
\hline 37 & 2 & 35.50 & 21.50 & 84.52 & 51.19 \\
\hline 38 & 2 & 35.50 & 21.50 & 84.52 & 51.19 \\
\hline 39 & 3 & 21.50 & 7.50 & 51.19 & 17.86 \\
\hline 40 & 2 & 34.68 & 20.72 & 83.19 & 50.26 \\
\hline 41 & 1 & 7.21 & 38.64 & 15.59 & 85.58 \\
\hline 42 & 3 & 21.67 & 8.50 & 56.19 & 18.86 \\
\hline
\end{tabular}

The revealed regularities of speed in the movement of points of the fist, elbow, knee and angles in the joints are also reflected in the trajectory of movement of the points of the fist, elbow, knee (Fig. 2 - 4). The athletes of cluster 1 "Speed and coordination endurance" have the most pronounced trajectory of the knee point movement (Fig. 2). Also, the trajectory of movement of the knee point among athletes of cluster 1 "Speed and coordination endurance", which is typical for athletes of the tempo 
style, is the lowest of all analyzed groups of athletes (Fig. 2).

The obtained facts can be explained by the fact that tempo-style boxers compensate for the lower level of speed of nervous processes by the speed of movement, which requires more flexion of the legs in the knee and hip joints. This causes a low stance during the fight and is displayed in the lower position of the knee point trajectory.

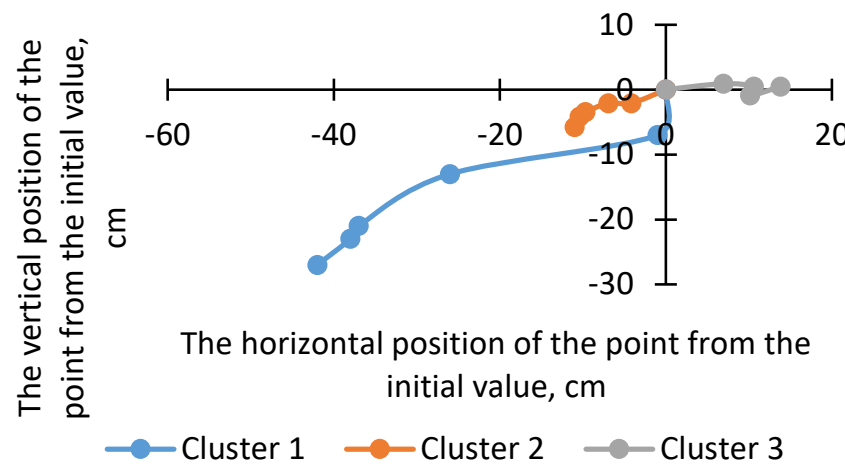

Fig. 3. Values of the trajectory of movement of the knee joint among qualified veteran boxers from different clusters:

Cluster $1-$ «Speed and coordination endurance»;

Cluster $2-\ll$ Speed $»$;

Cluster $3-$ «Strength and speed»

The athletes of the "Speed" cluster, which corresponds to the boxers of the playing style, have the highest trajectory of the fist point movement (Fig. 3 ). This is due to the fact that the high speed of hand movement and the general variability of the boxers' actions in this cluster allows them to act in a high stance and execute strikes along a high trajectory. In addition, for the development of a high speed of movement of the fist point, the most favorable position is a high stance of a boxer, since a high stance requires the least strength and the least manifestations of speed endurance. The lowest trajectory of the fist point movement among boxers of the tempo style, the cluster "Speed and coordination endurance" (Fig. 3). This is due to the lowest stance of the boxers in the tempo style of fighting. The trajectory of the fist movement in power style boxers, the "Strength and Speed" cluster, occupies an intermediate position. In playing style athletes, the point of fist ends the movement earlier than the other two fighting styles. This is due to the higher speed of execution of the blow by the boxers of the playing style, cluster "Speed".

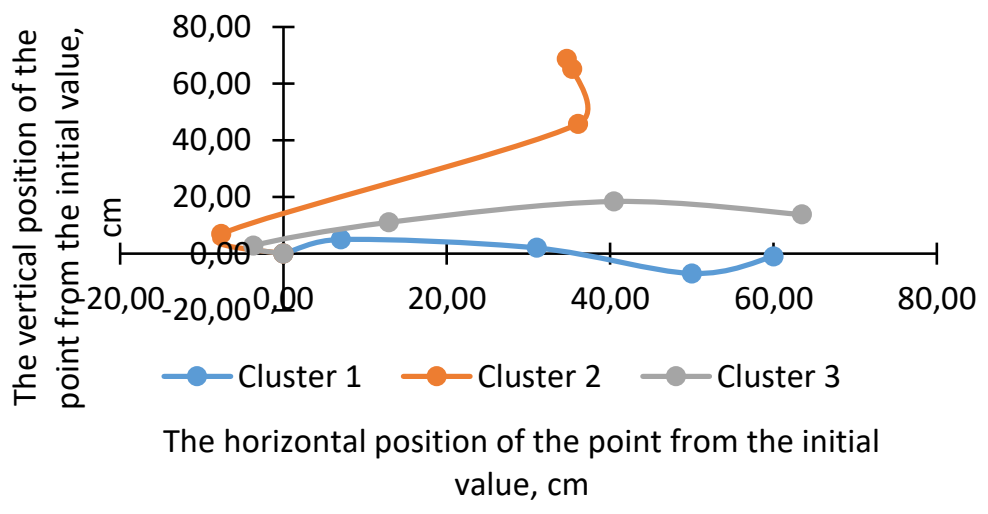

Fig. 4. Values of the trajectory of the fist movement among qualified veteran boxers from different clusters: Cluster $1-$ «Speed and coordination endurance»;

Cluster $2-«$ Speed»;

Cluster $3-$ «Strength and speed»

The trajectory of movement of the elbow joint is also the lowest in tempo style boxers, the cluster "Speed and coordination endurance" (Fig. 4).
This is also due to the lowest stance in the bout of these athletes. Also, the trajectory of the elbow point in tempo style athletes is characterized by an initial 
movement of the elbow back for a small swing, and then forward. At the end of the strike, the elbow point is practically at the same level for boxers of all analyzed styles. In playing style athletes, the elbow point finishes the movement earlier than boxers of the other two fighting styles (Fig. 4). This is due to the higher speed of execution of the blow by the boxers of the playing style, cluster "Speed".

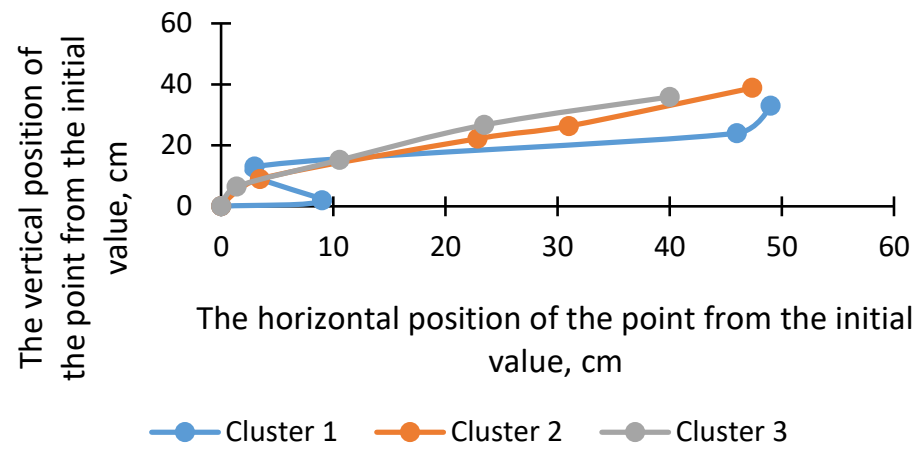

Fig. 5. Values of the trajectory of movement of the elbow joint among qualified veteran boxers from different clusters:

Cluster $1-\ll$ Speed and coordination endurance»;

Cluster $2-\ll$ Speed»;

Cluster $3-$ «Strength and speed»

\section{Discussion}

As far as we know, this study is one of the first to determine the fighting styles of qualified veteran boxers. In our study, we used cluster analysis to distribute boxers into groups based on biomechanical and psychophysiological indicators. This method was applied for the first time to determine the styles of competitive activity of veteran boxers.

In our study, the hypothesis was confirmed regarding the effectiveness of using the methods of multivariate analysis (in our case, cluster analysis) of biomechanical and psychophysiological indicators to determine the styles of fighting qualified veteran boxers.

Issues related to the style of activity have occupied the attention of psychologists for several decades, both in work and, especially, in sports. The problem of the style of activity is the problem of the highest level of achievement in the activity of each person, the problem of mastery and its formation, the problem of optimal "docking", balancing the subject with objective requirements $[1,2]$. Therefore, the most acceptable way of an individual approach is not to adjust the trainees' characteristics to a certain unified model, but to promote the formation of those techniques and methods of action that are most optimal for students and correspond to pronounced abilities. A person should look for individually unique ways of mastering the required qualities and skills, taking into account his natural inclinations; the insufficiency of some of them will have to be compensated for, while others will turn out to be favorable. Thus, the problem arises of the formation of an individual style of activity [3, 4]. Currently, the most effective in terms of ease of use and information content are psychophysiological indicators to determine the individual genetically determined factors in the formation of the style of activity [12$15]$.

Analysis of the research results in the aspect of comparing them with the available literature data showed that this work is one of the first in terms of determining the influence of the athlete's psychophysiological indicators in combination with the biomechanical data of individual technique on the formation of the style of fighting in boxing. The authors dealing with the issues of determining the styles of athletes' activity [3,5], do not consider the process of training athletes from the point of view of the system, analysis of a wide range of indicators of readiness. The authors dealing with this problem [6] focused on visual observation of the boxer's activity, without offering specific indicators for determining the style of fighting. In our study, the effectiveness of the use of objective indicators has been shown, which makes it possible to determine the propensity of a boxer to a certain style of fighting, which is the data obtained for the first time. At the same time, the possibilities of using congenital psychophysiological characteristics are not considered.

Psychophysiological features are decisive in the formation of an individual style of activity, one of the manifestations of which is the style of fighting in boxing. Our research expands, confirms and supplements the data presented in the works [7-9, 
12] regarding the informativeness of psychophysiological indicators for the current and operational control of the functional state of athletes and the determination of their individual characteristics. This is most important for predicting the results of competitive activity.

It should be noted that the problem considered in our work closely intersects with the problem of individualization of the training process considered in works [31-33] and is consistent with the concept of individualization presented in the works of Kozina [32-36]. The concept of individualization of the training process $[31,32]$ was developed using the deductive method. It lies in the fact that for the adequate construction of individual training programs it is necessary:

1 - to conduct comprehensive testing of athletes, which includes anthropometric, biomechanical, psychophysiological and other indicators;

2 - to carry out a factor analysis of the obtained indicators;

3 - to determine the individual factor structure of the complex fitness of athletes;

4 - to highlight the leading and lagging factors in the individual factor structure of athletes' fitness:

5 - to form groups of athletes according to the degree of similarity among themselves according to the individual factor structure of fitness or using cluster analysis of indicators of complex testing of athletes;

$6-$ develop and implement training programs for athletes of each group (cluster).

On the basis of the theoretical concept of individualization of the training process in sports, developed by Kozina [32], we determined the groups of boxers according to the indicators of complex testing. The concept assumes the use of an algorithm, which consists of the following stages [32, 33]: testing athletes, including a set of tests of at least 10; determination of the general structure of athletes' fitness by means of factor analysis. Determination of the main factors and drawing up their characteristics; conducting a hierarchical cluster analysis of testing indicators; determination of individual factor values; based on individual factor values and cluster analysis of compiling individual characteristics. Factor analysis with the determination of the individual severity of factors was carried out in our previous study [26]. In the study presented in the current work, the concept of individualization by Kozina was fully implemented [31-33]. The effectiveness of this concept was confirmed $[32,33]$ for determining the individual characteristics of athletes. In particular, we have applied this concept to define the fighting styles of qualified veteran boxers.

It should be noted that the methods of psychophysiological and biomechanical testing proposed in our work to determine the individual characteristics of boxers are an effective, informative and sufficiently accessible and convenient tool for identifying the predisposition of boxers to a certain style of fighting.

\section{Prospects for further research}

Further research suggests:

- identification of differences between boxers of different styles of fighting according to biomechanical and psychophysiological indicators;

- development and substantiation of recommendations regarding the construction of the training process of qualified veteran boxers of different styles of fighting.

\section{Limitations}

The study was conducted on qualified veteran boxers, therefore, the data obtained apply only to the studied contingent. Additional research is needed to disseminate the obtained data to boxers of other age and social groups, as well as to representatives of other sports.

\section{Conclusions}

1. Cluster analysis of psychophysiological testing showed the presence of 3 groups of athletes. 3 clusters (groups) of veteran boxers have been identified, which differ in their psychophysiological and biomechanical indicators. Athletes of the first cluster are dominated by the expression of qualities that determine the speed and coordination endurance (over 80\%) and a small level of expression of speed qualities (less than 30\%). This corresponds to the pace of the fight. The athletes of the second cluster are dominated by the expression of speed qualities (over $80 \%$ ) and the average level of expression of qualities that determine the speed and coordination endurance (about 50\%). This corresponds to the game style of the fight. Athletes of the third cluster have an average expression of speed qualities (about $50 \%$ ) and a small expression of qualities that determine speed and coordination endurance (less than $30 \%$ ). Approximation of the obtained results to the expression of different qualities made it possible to determine the greatest manifestation of the speed and strength qualities of the boxers of the third cluster. This corresponds to the power style of the 
fight. The clusters were named as follows: Cluster 1 - "Speed and coordination endurance", corresponds to the boxers of the pace of the fight; Cluster 2 "Speed", corresponds to the boxers of the game style of fighting; Cluster 3 - "Strength and speed", corresponds to the boxers of the pace of the fight.

2. Biomechanical features of boxers of different styles of fighting are reflected in the trajectories of the points of the fist, elbow, knee. The athletes of the "Speed and coordination endurance" cluster (tempo style boxers) have the most pronounced trajectory of knee point movement. The trajectory of movement of the knee point in tempo style athletes is the lowest of all analyzed groups of athletes. The athletes of the "Speed" cluster, which corresponds to the boxers of the playing style, have the highest trajectory of the fist point movement. The lowest trajectory of the fist point movement among boxers of the tempo style, the "Speed and coordination endurance" cluster. The trajectory of movement of the elbow joint is also the lowest in tempo style boxers, cluster "Speed and coordination endurance".

3. It is advisable to use the results of this research when planning the individual training of athletes in boxing and to determine the optimal style of conducting a competitive combat for qualified veteran boxers. The proposed methods of psychophysiological and biomechanical testing to determine the individual characteristics of boxers are an effective, informative and fairly accessible and easy-to-use tool for revealing the predisposition of boxers to a certain style of fighting.

\section{Acknowledgments}

The authors are very grateful to all the athletes and coaches who took part in the experiment.

The study was conducted according to: research work on the topic of the Department of Olympic and Professional Sports, Sports Games and Tourism of H.S. Skovoroda Kharkiv National Pedagogical University for 2021 - 2026: "Development and substantiation of technologies for health promotion and harmonious development of people of different ages and social groups" (№ state registration: 0121U110053).

\section{Conflict of interest}

The authors declare that there is no conflict of interest.

\section{References}

1. Korobeynikov G, Aksutin V, Smoliar I. Connection of boxers' combat styles with psycho-physiological characteristics. Pedagogics, psychology, medicalbiological problems of physical training and sports. 2015;19(9):33-7. https://doi.org/10.15561/18189172.2015.0905

2. Safronov DV, Kozin VYu, Kozina ZhL, Basenko AV, Riabenkov IO, Khrapov SB. Determining the style of conducting a fight of qualified boxers based on neurodynamic indicators using multivariate analysis methods. Health, sport, rehabilitation, 2019; 5(2): 7887. doi:10.34142/HSR.2019.05.02.09

3. Coswig VS, Gentil P, Irigon F, Del Vecchio FB. Caffeine ingestion changes time-motion and technicaltactical aspects in simulated boxing matches: A randomized double-blind PLA-controlled crossover study. European Journal of Sport Science. 2018;18(7):975-83.

4. Andersen W. Sport and self-love: reflections on boxing and the construction of selfhood. Journal of the Philosophy of Sport. 2021;48(1):129-45.

5. Davis P, Connorton AJ, Driver S, Anderson S, Waldock R. The activity profile of elite male amateur boxing after the 2013 rule changes. Journal of strength and conditioning research. 2018;32(12):3441-6.

6. Narici M, McPhee J, Conte M, Franchi MV, Mitchell $\mathrm{K}$, Tagliaferri S, et al. Age-related alterations in muscle architecture are a signature of sarcopenia: the ultrasound sarcopenia index. Journal of Cachexia Sarcopenia and Muscle. 2021;12(4):973-82.

7. Korobejnikov GV, Korobejnikova LG, Kozina ZL. Evaluation and correction of physiological states in sports, Kharkiv, KNPU, 2012.

8. Korobeynikov G, Korobeynikova L, Romanyuk L, Dakal N, Danko G. Relationship of psychophysiological characteristics with different levels of motivation in judo athletes of high qualification. Pedagogics, psychology, medicalbiological problems of physical training and sports. 2017;21(6):272-8.

https://doi.org/10.15561/18189172.2017.0603 doi: 10.15561/18189172.2017.0603

9. Korobejnikov GV, Aksjutin VV, Smoljar II. Svjaz' stilja vedenija poedinka bokserov s razlichnymi psihofiziologicheskimi harakteristikami [Relationship of boxing style of introduction of boxers with different psychophysiological characteristics]. Pedagogika, psihologija $i$ mediko-biologicheskie problemy fizicheskogo vospitanija i sporta. 2015; 9:33-37.

10. Follmer B, Varga AA, Zehr EP. Understanding concussion knowledge and behavior among mixed martial arts, boxing, kickboxing, and Muay Thai athletes and coaches. Physician and Sportsmedicine. 2020;48(4):417-23. 
11. Cañizares Hernández M, Soler Prieto Y, Domínguez García J, Suárez Rodríguez M. Factors affecting concentration of attention in boxing athletes in combat situations Los factores que afectan la concentración de la atención en atletas de boxeo en situaciones de combate. Podium Revista de Ciencia y Tecnología en la Cultura Física. 2020;15(1):5-21.

12. Lyzohub V, Nechyporenko L, Pustovalov V, Suprunovych V. Specialized training and bioenergy state of football players with different typological properties of the higher parts of the nervous system. Science and Education. 2016;8:107-112; doi: 10.24195/2414-4665-2016-8-21.

13. Howell DR, Meehan WP, Loosemore MP, Cummiskey J, von Rosenberg JPG, McDonagh D. Neurological tests improve after Olympic-style boxing bouts: a pretournament and post-tournament study in the 2016 Women's World Boxing Championships. British Journal of Sports Medicine. 2017;51(17):1279-84.

14. Kozina Z, Barybina L, Mishchenko D, Tsikunov A, Kozin A. The program "Psychodiagnostics" as a means of determining psycho-physiological characteristics and functional state in the physical education of students. Physical education of students. 2011;3:56-59.

15. Iermakov SS, Kozina ZL, Ceslitska M, Mushketa R. Razrabotka kompyuternyih programm dlya opredeleniya psihofiziologicheskih vozmozhnostey i svoystv nervnoy sistemyi lyudey s raznyim urovnem fizicheskoy aktivnosti [Computer program development for determination of psychophysiological possibilities and properties of thenervous system of people with the different level of physicalactivity]. Zdorov'â, sport, reabilitaciâ [Health, sport, rehabilitation], 2016; 2(1): 14-18.

16. Finlay MJ, Greig M, Page RM. Quantifying the physical response to a contemporary amateur boxing simulation. Journal of Strength and Conditioning Research. 2018;32(4):1005-12.

17. Shadmehr R, Wise S. The computational neurobiology of reaching and pointing: a foundation for motor learning. Cambridge, Mass.: MIT Press. 2005. $\underline{\text { ISBN }}$ 978-0-262-19508-9. OCLC 54529569.

18. Paul M, Ganesan S, Sandhu JS, Simon JV. Effect of sensory motor rhythm neurofeedback on psychophysiological, electro-encephalographic measures and performance of archery players. Ibnosina J. Med. Biomed. Sci. 2011:32-39.

19. Deary IJ, Der G, Ford G. Reaction times and intelligence differences; a population-based cohort study. Intelligence. 2001;29(5):389-399. doi: 10.1016/S0160-2896(01)00062-9.

20. Hedayatpour N, Falla D. Physiological and Neural Adaptations to Eccentric Exercise: Mechanisms and Considerations for Training. BioMed Research International. 2015;(15):7. https://doi.org/10.1155/2015/193741.

21. Cacioppo J, Tassinary LG, Berntson GG. The handbook of psychophysiology, $3^{\text {rd }}$ ed. New York: Cambridge University Press; 2007.

22. Bart K, Steinberg H. The Contributions of the East-
German Sports Medicine Specialist and Neurologist Bernhard Schwarz (1918-1991) in the Field of Boxing. Sportverletzung-Sportschaden. 2018;32(1):66-74.

23. Bingul BM, Bulgan C, Tore O, Aydin M, Bal E. The effects of impact forces and kinematics of two different stances at straight punch techniques in boxing. Archives of Budo Science of Martial Arts and Extreme Sports. 2017;13:35-9.

24. El-Ashker S, Chaabene H, Negra Y, Prieske O, Granacher U. Cardio-Respiratory Endurance Responses Following a Simulated 3 x 3 Minutes Amateur Boxing Contest in Elite Level Boxers. Sports. 2018;6(4).

25. Boroushak N, Khoshnoodi H, Rostami M. Investigation of the Head's Dynamic Response to Boxing Punch Using Computer Simulation. Montenegrin Journal of Sports Science and Medicine. 2021;10(1):31-5.

26. Kozin V, Boychuk Y, Skaliy A, Zelenskiy R, Honcharenko V. Individual Factorial Structure of Biomechanical and Psychophysiological Indicators as a Basis for Determining the Fighting Style of Qualified Veteran Boxers. Zdor. sport reabil. [Health, Sport, Rehabilitation]. $2021 ; 7(3): 8-30$. https://doi.org/10.34142/HSR.2021.07.03.01.

27. Chen MA, Spanton K, van Schaik P, Spears I, Eaves D. The Effects of Biofeedback on Performance and Technique of the Boxing Jab. Perceptual and Motor Skills. 2021;128(4):1607-22.

28. Lenetsky S, Brughelli M, Nates RJ, Neville JG, Cross MR, Lormier AV. Defining the Phases of Boxing Punches: A Mixed-Method Approach. Journal of Strength and Conditioning Research. 2020;34(4):1040-51.

29. Kozin S, Safronov D, Kozina Z, Kniaz H, Proskurnia O, Prontenko K, Lahno O, Goncharenko V, Kholodniy A. Comparative biomechanical characteristics of onearm hang in climbing for beginners and qualified athletes. Acta of Bioengineering and Biomechanics. 2020;22(1):57-67.DOI: 10.37190/ABB-01440-201903.

30. Kozin S, Kozina Z, Korobeinik V, Cieślicka M, Muszkieta R, Ryepko O, Boychuk Yu, Evtifieva I, Bejtka M. Neuro-muscular training for injury prevention of students-rock climbers studying in the specialty "Physical Education and Sports": a randomized study. Journal of Physical Education and Sport. 2021;21(Suppl. issue 2):1251 - 1259.

31. Kozina ZL, Cieslicka M, Prusik K, Muszkieta R, Sobko IN, Ryepko OA, Bazilyuk TA, Polishchuk SB, Osiptsov AV, Korol SA. Algorithm of athletes' fitness structure individual features' determination with the help of multidimensional analysis (on example of basketball). Physical education of students. 2017;21(5):225-238.

http://dx.doi.org/10.15561/20755279.2017.0505

32. Kozina ZhL. Algoritm sistemnogo analiza v nauchnykh issledovaniyakh $\mathrm{v}$ oblasti sportivnykh igr [Algorithm for systems analysis in scientific research in the field of sports games]. Fizicheskoye vospitaniye 
studentov tvorcheskikh spetsial'nostey. 2006; 1(4): 1526

33. Kozina ZhL. Analiz i obobshchenie rezul'tatov prakticheskoj realizacii koncepcii individual'nogo podkhoda $\mathrm{v}$ trenirovochnom processe $\mathrm{v}$ sportivnykh igrakh [Analysis and generalization of results of practical realization of individual approach conception in trainings of sport games]. Fizicheskoe vospitanie studentov tvorcheskikh special'nostej. 2009; 2: 34-47.

34. Kozina ZL, Goloborodko YA, Boichuk YD, Sobko IM, Repko OO, Bazilyuk TA, et.al. The influence of a special technique for developing coordination abilities on the level of technical preparedness and development of psycho-physiological functions of young volleyball players 14-16 years of age. Journal of Physical Education and Sport. 2018; 18(3):1445-1454.
DOI:10.7752/jpes.2018.03214

35. Kozina Z. Factor models of the physical preparedness of volleyball players of a high class of various game role. Pedagogy, Psychology and medical and biological problems of physical education and sport, 2007;9: 80-85.

36. Kozina ZhL, Slyusarev VF, Volkov EP. Efektivnist' zastosuvannia netradicijnoi formi autogennogo trenuvannia dlia vidnovlennia pracezdatnosti basketbolistiv [Effectiveness of non-traditional form of autogenic training for recreation of basketball players; workability]. Pedagogics, psychology, medical-biological problems of physical training and sport. 2001; 14: 8-15

\section{Information about authors}

\section{Kozin V.Yu.}

http://orcid.org/0000-0003-2561-8803

kozin.v.yu@gmail.com

Kinesiology laboratory

H.S. Skovoroda Kharkiv National Pedagogical University

Head of the Kinesiology laboratory

Altshevskih str. 29, Kharkiv, 61002, Ukraine

\section{Falova O.Ye.}

alyonafalyova@ukr.net

http://orcid.org/0000-0001-5983-0090

Department of Practical Psychology

Ukrainian Engineering Pedagogics Academy

Doctor of Psychology Sciences, Associate Professor

Universytetska str. 16, Kharkiv, Ukraine, 61003

\section{Cretu M.}

https://orcid.org/0000-0003-1934-0534

cmaryan_mc@yahoo.com

Faculty of Science, Physical Education and Informatics; University of Pitesti

Str. Targul din Vale, nr.1, 110040 Pitesti, Arges, Romania

\section{Cieślicka M.}

cudaki@op.pl

http://orcid.org/0000-0002-0407-2592

Nicolaus Copernicus University in Toruń, Ludwik Rydygier Collegium Medicum in Bydgoszcz

Bydgoszcz, Kujawsko-pomorskie, Poland

Козін В.Ю.

\section{Інформація про авторів}

http://orcid.org/0000-0003-2561-8803;

kozin.v.yu@gmail.com

Лабораторія кінезіології

Харківський національний педагогічний університет імені Г.С. Сковороди

вул. Алчевських 29, Харків, 61002, Україна

Завідувач лабораторії кінезіології

Altshevskih str. 29, Kharkiv, 61002, Ukraine 


\section{Фальова О.С.}

alyonafalyova@ukr.net

http://orcid.org/0000-0001-5983-0090

Українська інженерно-педагогічна академія

Кафедра практичної психології

Доктор психологічних наук, доцент

вул. Університетська, 16, м. Харків, Україна, 61003

\section{Крету М.}

https://orcid.org/0000-0003-1934-0534

cmaryan_mc@yahoo.com

Факультет науки, фізичного виховання та інформатики, Університет Пітесті вул. Таргундін Вале, 1, 110040, Пітесті, Румунія

\section{Цесліцка М.}

cudaki@op.pl

http://orcid.org/0000-0002-0407-2592

Університет Миколи Коперника в Торуні

Бидгощ, Куявсько-Поморське воєводство, Польща

\section{Козин В.Ю.}

\section{Информация об авторах}

http://orcid.org/0000-0003-2561-8803

kozin.v.yu@gmail.com

Лаборатория кинезиологии

Харьковский национальный педагогический университет имени Г.С. Сковороды

Заведующий лаборатории кинезиологии

ул. Алчевских 29, Харьков, 61002, Украина

\section{Фалева Е.E.}

alyonafalyova@ukr.net

http://orcid.org/0000-0001-5983-0090

Украинская инженерно-педагогическая академия

Кафедра практической психологии

Доктор психологических наук, доцент

ул. Университетская, 16, г. Харьков, Украина, 61003

\section{Крету М.}

https://orcid.org/0000-0003-1934-0534

cmaryan_mc@yahoo.com

Факультет науки, физического воспитания и информатики, Университет Питести

Ул. Таргундин Вале, 1, 110040, Питести, Румыния

\section{Цеслицка М.}

cudaki@op.pl

http://orcid.org/0000-0002-0407-2592

Университет Николая Коперника в Торуне

Быдгощ, Куявско-Поморское воеводство, Польша

This work is licensed under a Creative Commons Attribution 4.0 International License (CC BY 4.0)

Received: 2021-09-08 Accepted: 2021-09-20 Published: 2021-12-25 